УдК 344.7

DOI https://doi.org/10.32837/pyuv.v0i2(31).575

\author{
A. М. Соцька \\ orcid.org/0000-0002-6633-9192 \\ кандидат юридичних наук, \\ заступник завідувача відділу забезпечення діяльності \\ Уповноваженого Президента України з прав людей з інвалідністю \\ Департаменту забезпечення діяльності уповноважених, \\ представників та роботи Офісу Президента Украӥни
}

\title{
ОСОБЛИВОСТІ ДЕРЖАВНОї ПОЛІТИКИ ЩОДО ЗАХИСТУ ОСІБ 3 ІНВАЛІДНІСТЮ ВІД ІНФЕКЦІЙНИХ ХВОРОБ
}

Значущість питання захисту осіб з інвалідністю від інфекційних хвороб у контексті його правового регулювання очевидна та визнана. Тим паче тепер - за умов коронавірусної хвороби. Свідоме досить високою мірою проблемами зазначеної категорії населення суспільство зіштовхнулося з відсутністю належного правового та соціального захисту осіб з інвалідністю в час інфекційної кризи.

Зазначена категорія населення вкрай уразлива перед такими захворюваннями через суб'єктивні й об'єктивні чинники, серед яких проблеми зі здоров'ям, зумовлені інвалідністю, бар'єрність зовнішнього середовища, зубожіння, часткове чи повне нехтування їхніми потребами на етапах прийняття відповідних рішень щодо інфекційних хвороб і їх реалізації тощо.

Реалії сьогодення дають можливість окреслити проблематику з питання захисту осіб з інвалідністю від інфекційних хвороб. Слід наголосити, що наукові дослідження за задекларованою темою відсутні. Водночас тією чи іншою мірою питань захисту населення від інфекційних хвороб у своїх працях торкалися Р. Гревцова, О. Губанова, Л. Жаліло, В. Кий-Кокарєва, О. Кононенко, А. Котвіцька, І. Кубарєва, В. Москаленко, Я. Радиш, І. Солоненко, І. Старченко та ін.

Ураховуючи зазначене, маємо за мету визначитися зі змістом державної політики щодо захисту осіб з інвалідністю від інфекційних хвороб, а особливо з недоліками законодавчого забезпечення цієї сфери.

Красномовно про проблему захисту осіб з інвалідністю за умов інфекційних захворювань говорить заява Верховного комісара ООН із прав людини Мішель Бачелет: «Люди з інвалідністю менше за інших захищені від COVID-19. Введені обмеження, включаючи ізоляцію, створюють для них значно більше труднощів... За умов пандемії люди з інвалідністю не почуваються в безпеці у своїх власних будинках, оскільки через заходи ізоляції вони позбавлені повсякденної підтримки і послуг. А деякі з них сильно страждають через самоізоляцію» [1].

Сьогодні існує безліч проблемних питань, пов'язаних із забезпеченням прав і законних інтересів осіб з інвалідністю під час пандемій. Серед них такі: 1) чи враховано та яким чином питання інвалідності у спеціальному законодавстві; 2) чи передбачено в місцевих програмах заходи, у т. ч. матеріального характеру, з надання допомоги особам з інвалідністю, які опинилися у складних життєвих обставинах, під час інфекційних криз; 3) чи можливо особі з інвалідністю 3 порушеннями зору, слуху, психічними розладами та розумовою відсталістю отримати в доступних форматах інформацію про інфекційні хвороби, їх спалахи та боротьбу з такими хворобами, про захист від них і відповідну допомогу; 4) де та яким чином отримуватиме необхідну медичну допомогу особа з інвалідністю з урахуванням бар'єрності зовнішнього середовища, фінансової неспроможності та необхідності самоізоляції; 5) який рівень обізнаності медичного персоналу з надання медичних послуг особам з інвалідністю, хворим на інфекційні хвороби; 6) чи ведеться статистика щодо ураження осіб з інвалідністю інфекційними захворюваннями; 7) хто доглядатиме за особою з інвалідністю в разі, коли захворіє відповідальна за такий догляд особа? Перелік таких проблем невичерпний.

Причиною виникнення та існування цих і безлічі інших проблем у досліджуваній сфері вважаємо недосконалу державну політику захисту населення від інфекційних хвороб загалом та осіб 3 інвалідністю зокрема. На нашу думку, державна політика відповідного спрямування є сукупністю цілей, заходів, рішень і дій із публічного адміністрування розвитку країни у напрямі реалізації виробленого політичного курсу з метою досягнення конкретної політичної мети щодо захисту населення від інфекційних хвороб з урахуванням питання інвалідності.

Переконані, що ефективність і результативність державної політики за будь-яким напрямом значною мірою залежить від політичної волі, яка $€$ рушійною силою у прийнятті тих чи інших рішень, оскільки спрямована на перетворення дійсності в інтересах і цілях суспільства в рамках законодавчого поля. 
Зосередившись на аналізі нормативно-правових актів із досліджуваного питання, вважаємо цілком обґрунтованим висновок стосовно того, що національне законодавство у сфері захисту населення від інфекційних хвороб не витримує жодної критики на предмет врахування потреб осіб з інвалідністю.

Основними нормативно-правовими актами в досліджуваній галузі, які теоретично мали б містити норми-гарантії щодо захисту осіб з інвалідністю від інфекційних хвороб, є такі: Конституція України (ст. 49) [2], Основи законодавства України про охорону здоров'я [3], Закони України «Про захист населення від інфекційних хвороб» [4], «Про забезпечення санітарного та епідеміологічного благополуччя населення» [5], «Про затвердження Загальнодержавної програми імунопрофілактики та захисту населення від інфекційних хвороб на 2009-2015 рр.» [6], постанова Кабінету Міністрів України від 22 серпня 2011 р. № 893 «Про затвердження Правил санітарної охорони території України» [7], накази Міністерства охорони здоров'я України від 17 травня 2019 р. № 1126 «Про затвердження Порядку організації проведення епідеміологічного нагляду за грипом та гострими респіраторними вірусними інфекціями, заходів з готовності в міжепідемічний період і реагування під час епідемічного сезону захворюваності на грип та ГРВI» [8], від 10 січня 2006 р. № 1 «Про затвердження Форм первинної облікової документації з інфекційної, дерматовенерологічної, онкологічної захворюваності та інструкцій щодо їх заповнення» (зареєстровано в Міністерстві юстиції України 8 червня 2006 р. за № 686/12560) [9] тощо.

Так, Основи законодавства України про охорону здоров'я не містять гарантій щодо забезпечення прав і потреб осіб з інвалідністю під час здійснення заходів із запобігання інфекційним захворюванням, небезпечним для населення [3].

Водночас питання інвалідності у профільному Законі України «Про захист населення від інфекційних хвороб» [4] згадується лише в нормі п. 1 ч. 2 ст. 39 , якою регламентовано розмір державних страхових виплат медичним працівникам державних і комунальних закладів охорони здоров'я в разі встановлення групи інвалідності протягом одного календарного року, яка настала внаслідок захворювання коронавірусною хворобою (COVID-19), за умови, що таке захворювання пов'язане з виконанням професійних обов'язків в умовах підвищеного ризику зараження.

Певний підтекст відповідного змісту можна знайти в абз. 5 і 6 ст. 5 цього Закону [4], у яких зазначено, що органи місцевого самоврядування у сфері захисту населення від інфекційних хвороб забезпечують доступність і безоплатність надання медичної допомоги хворим на інфекційні хворо- би у державних і комунальних закладах охорони здоров'я; забезпечують відповідно до законодавства громадян пільгових категорій лікарськими засобами та виробами медичного призначення для лікування і профілактики інфекційних хвороб. Незрозуміло, про яку доступність ідеться та яких громадян пільгових категорій зазначена гарантія стосується. Загальновідомо, що рівень, для прикладу, архітектурної доступності медичних закладів є вкрай низьким. Тож постає питання, наскільки реалістичною є гарантія безоплатного проведення медичних оглядів та обстежень осіб з інвалідністю, хворих на інфекційні хвороби, у державних і комунальних закладах охорони здоров' я та державних наукових установах лікування.

Також слід зазначити, що в ч. 6 ст. 12 Закону України «Про захист населення від інфекційних хвороб» [4] визначено умови проведення профілактичних щеплень особам, визнаним в установленому законом порядку недієздатними й обмежено дієздатними. Значна частина таких осіб має інвалідність унаслідок психічних чи інтелектуальних порушень.

Водночас статті цього спеціального Закону України [4], у яких ідеться про органи державної влади, не містять окремих положень, які б стосувалися повноважень щодо забезпечення захисту осіб з інвалідністю від інфекційних хвороб.

Жодної вимоги у ст. 31 Закону України «Про захист населення від інфекційних хвороб» [4] i стосовно доступності для осіб з інвалідністю обсерваторів, тимчасових закладів охорони здоров'я (спеціалізованих шпиталів).

У Законі України «Про забезпечення санітарного та епідеміологічного благополуччя населення» [5] питання інвалідності згадується лише раз у ст. 48 , в якій закріплено норму про відшкодування збитків громадянам у разі порушення санітарного законодавства, що призвело і до інвалідності. Що стосується надважливих питань публічного адміністрування відносин у регламентованій згаданим Законом сфері, здійснення державного санітарно-епідеміологічного нагляду в Україні, то вони не включають питань інвалідності усупереч тому, що повною мірою стосуються прав та інтересів відповідної категорії осіб.

Хоча в Загальнодержавній програмі імунопрофілактики та захисту населення від інфекційних хвороб на 2009-2015 pp. [6] і було зазначено, що інфекційні хвороби є однією з основних причин інвалідності населення в усьому світі, а також однією з цілей визначено забезпечення епідемічного благополуччя населення шляхом зниження рівня інвалідності внаслідок інфекційних хвороб, проте жоден захід згаданої Програми не стосувався осіб 3 інвалідністю.

У Правилах санітарної охорони території України, затверджених постановою Кабінету Міністрів 
України від 22 серпня 2011 р. № 893 [7], як основному документі, яким визначається механізм здійснення організаційних медико-санітарних, санітарно-гігієнічних, лікувально-профілактичних і протиепідемічних заходів, спрямованих на запобігання занесенню та поширенню на територію України інфекційних хвороб, взагалі не йдеться про забезпечення прав і законних інтересів осіб з інвалідністю.

Сьогодні за умов поширеності коронавірусної хвороби не відома чисельність осіб з інвалідністю, котрі захворіли, одужали та померли від COVID-19. Також відсутня статистика про щеплення осіб з інвалідністю проти інфекційних хвороб. Наказ Міністерства охорони здоров'я України від 10 січня 2006 р. № 1 «Про затвердження Форм первинної облікової документації з інфекційної, дерматовенерологічної, онкологічної захворюваності та інструкцій щодо їх заповнення» (зареєстровано в Міністерстві юстиції України 8 червня 2006 р. за № 686/12560) [9] також не містить жодної згадки про осіб з інвалідністю. Тож немає статистики - немає проблеми. Те саме стосується і Порядку організації проведення епідеміологічного нагляду за грипом і гострими респіраторними вірусними інфекціями, заходів із готовності в міжепідемічний період і реагування під час епідемічного сезону захворюваності на грип та ГРВІ [8].

Окремо слід зазначити, що в разі загрози чи виникнення або поширення інфекційних хвороб для осіб з інвалідністю з порушенням зору, слуху та психічними розладами й розумовою відсталістю особливу небезпеку несе інформаційна бар'єрність, адже відсутність інформації про епідемічну ситуацію обеззброює і тим самим наражає на ще більший ризик захворювання.

Усупереч цьому поза увагою в нормативно-правових актах у сфері захисту населення від інфекційних хвороб залишилися питання інформування осіб з інвалідністю про епідемічну ситуацію та здійснювані протиепідемічні заходи (тож під сумнівом реалізація особами з інвалідністю права на отримання достовірної інформації щодо епідемічної ситуації в Україні через засоби масової інформації, інтернет-ресурси та в органах влади, працівники яких, для прикладу, не володіють навіть азами жестової мови. Дещо краща ситуація з телевізійними 3МI); врахування потреб зазначеної категорії населення під час планування та здійснення організаційних, фінансових та інших заходів, спрямованих на запобігання, профілактику, боротьбу, ліквідацію епідемій і спалахів інфекційних хвороб тощо.

Національна рада України з питань телебачення і радіомовлення, з огляду на надзвичайну ситуацію, викликану пандемією COVID-19, від якої вже померли тисячі людей у всьому світі, висловила сподівання на соціальну відповідальність вітчизняних медіа і рекомендувала мовникам за можливості забезпечити субтитрування та/або сурдопереклад випусків новин та офіційних виступів представників органів влади з питань, які стосуються поширення коронавірусу COVID-19, а також запроваджених в Україні заходів протидії йому [10].

Як свідчить практика, відсутність деталізації питання інвалідності в законодавстві рівноцінна нехтуванню прав і потреб осіб відповідної категоpiї. Вважаємо, що такий стан справ зумовлений відсутністю політичної волі та пасивністю громадянського суспільства. Як наслідок, на практиці в умовах інфекційних криз представники зазначеної категорії осіб не можуть реалізувати конституційне право на охорону здоров'я. Окрім того, в умовах пандемій потреби осіб з інвалідністю ігноруються не лише у сфері охорони здоров'я, а й у всіх сферах їх життедіяльності.

Тому залишається сподіватися, що потреби осіб з інвалідністю враховуватимуться в умовах загрози або виникнення інфекційних хвороб незалежно від того, чи відповідні питання відображені в нормах і положеннях національного законодавства в цій сфері. Особливо коли йдеться про хворих на соціально небезпечні інфекційні хвороби осіб, значна кількість яких має інвалідність, зокрема, для прикладу, носіїв туберкульозу.

Однак той факт, що норма ст. 25 Закону України «Про захист населення від інфекційних хвороб» [4] про право осіб, які хворіють на туберкульоз в активній формі, на першочергове поліпшення житлових умов у порядку, встановленому законодавством, є мертвою, вселяє сумніви щодо якості й ефективності захисту населення від інфекційних хвороб, тим паче осіб з інвалідністю.

Особи з інвалідністю потерпають як безпосередньо від інфекційних захворювань, так і від наслідків, які такі захворювання зумовлюють для осіб зазначеної категорії, котрі не є носіями інфекції, адже й без того недостатня увага до їхніх проблем перефокусовується на боротьбу з вірусами.

За умов спалахів інфекційних хвороб життєво необхідно забезпечувати доступ осіб з інвалідністю (особливо тих осіб, які перебувають у закладах інституційного догляду або потребують постійного стороннього догляду) до усіх послуг, що надаються населенню, передусім медичних. Не менш важливо залучати громадянське суспільство у сфері соціальної та правової захищеності осіб з інвалідності до прийняття рішень із питання захисту та боротьби з інфекційними хворобами для забезпечення прав і законних інтересів осіб з інвалідністю, оскільки всі без винятку заходи щодо попередження, лікування та ліквідації інфекційних хвороб повинні враховувати аспект інвалідності. 


\section{Jimepamypa}

1. Верховний комісар $\mathrm{OOH}$ закликала держави захистити осіб з інвалідністю. 13 травня 2020 p. URL: https://ukrainepravo.com/international_law/public international_law/verkhovnyy-komisar-oon-zaklykaladerzhavy-zakhystyty-osib-z-invalidnistyu/.

2. Конституція України від 26 червня 1996 р. Відо мості Верховної Ради України. 1996. № 30. Ст. 141.

3. Основи законодавства України про охорону здоров'я : Закон України від 19 листопада 1992 р. № 2801-XII. Відомості Верховної Ради України. 1993. № 4. Ст. 19.

4. Про захист населення від інфекційних хвороб : Закон України від 6 квітня 2000 р. № 1645-III. Відолості Верховної Ради України. 2000. № 29. Ст. 228.

5. Про забезпечення санітарного та епідеміологічного благополуччя населення : Закон України від 24 лютого 1994 р. № 4004-XII. Відомості Верховної Ради України. 1994. № 27. Ст. 218.

6. Про затвердження Загальнодержавної програми імунопрофілактики та захисту населення від інфекційних хвороб на 2009-2015 рр. : Закон України від 21 жовтня 2009 р. № 1658-VI. Відомості Верховної Ради України. 2010. № 2-3. Ст. 12.

7. Про затвердження Правил санітарної охорони території України : постанова Кабінету Міністрів України від 22 серпня 2011 р. № 893. Офіиійний вісник України. 2011. № 65. Ст. 2538.

8. Про затвердження Порядку організації проведення епідеміологічного нагляду за грипом та гострими респіраторними вірусними інфекціями, заходів 3 готовності в міжепідемічний період і реагування під час епідемічного сезону захворюваності на грип та ГРВI : наказ Міністерства охорони здоров’я України від 17 травня 2019 р. № 1126. Офіиійний вісник України. 2019. № 51. Ст. 1762.

9. Про затвердження Форм первинної облікової документації 3 інфекційної, дерматовенерологічної, онкологічної захворюваності та інструкцій щодо їх заповнення : наказ Міністерства охорони здоров'я України від 10 січня 2006 р. № 1. Офіиійний вісник України. 2006. № 24. Ст. 1779.

10. Регулятор закликає мовників забезпечити субтитрування чи сурдопереклад інформації про коронавipyc COVID-19. URL: https://naiu.org.ua/regulyatorzaklykaye-movnykiv-zabezpechyty-subtytruvannya-chysurdopereklad-informatsiyi-pro-koronavirus-covid-19/.

\section{Анотація}

Соцька A. М. Особливості державної політики щодо захисту осіб з інвалідністю від інфекційних хвороб. - Стаття.

Стаття присвячена прогалинам у законодавчому регламентуванні захисту осіб з інвалідністю від інфекційних хвороб. Окрім іншого, в тексті зазначено про основні проблеми, з якими зіштовхуються представники зазначеної категорії населення як із числа захворілих на інфекційні захворювання осіб, так і загалом осіб з інвалідністю. Тим самим окреслено ключові напрями вдосконалення державної політики у сфері охорони здоров'я в напрямі розвитку законодавства 3 питання захисту населення від інфекційних хвороб і практики його реалізації відповідно. Також охарактеризовано основні нормативно-правові акти, норми та положення яких визначають механізм захисту населення від інфекційних хвороб, на предмет врахування потреб осіб з інвалідністю. Серед зазначених законодавчих актів - закони України й акти Кабінету Міністрів України та Міністерства охорони здоров’я
України. 3'ясовано, що національне законодавство не містить спеціальних гарантій для осіб з інвалідністю стосовно їх захисту від інфекційних хвороб, не передбачає спеціальних заходів публічного адміністрування цією сферою, які б були спрямовані на забезпечення потреб осіб з інвалідністю. Тож установлено потребу в законодавчій регламентації питань врахування потреб осіб з інвалідністю в усіх аспектах державної політики щодо захисту населення від інфекційних хвороб, забезпечення доступу осіб з інвалідністю до медичних та інших видів послуг за умов інфекційних криз, забезпечення доступності інформації про інфекційні хвороби для осіб з інвалідністю всіх нозологій, збору статистичних даних про захворюваність осіб з інвалідністю на інфекційні хвороби тощо.

Акцентовано увагу на значенні участі громадянського суспільства у сфері соціальної та правової захищеності осіб з інвалідністю до прийняття рішень із питання захисту та боротьби з інфекційними хворобами для забезпечення прав і законних інтересів осіб з інвалідністю, оскільки всі без винятку заходи щодо попередження, лікування та ліквідації інфекційних хвороб повинні враховувати аспект інвалідності. За умов спалахів інфекційних хвороб життєво необхідно забезпечувати доступ осіб з інвалідністю (особливо тих осіб, якіперебувають узакладах інституційного догляду або потребують постійного стороннього догляду) до усіх послуг, що надаються населенню, передусім медичних.

Ключові слова: особа з інвалідністю, інфекційна хвороба, пандемія, державна політика, охорона здоров'я.

\section{Summary}

Sotska A. M. Peculiarities of state policy regarding protection of persons with disabilities from infectious diseases. - Article.

The article is devoted to gaps in the legislative regulation of protection of persons with disabilities from infectious diseases. Among other things, the text mentions the main problems faced by the representatives of this category of the population both from the number of people suffering from infectious diseases and people with disabilities in general. This outlines the key areas for improving public health policy in the direction of developing legislation to protect the population from infectious diseases and the practice of its implementation, respectively. The main normative legal acts are also characterized, the norms and provisions of which determine the mechanism of protection of the population from infectious diseases, in order to take into account the needs of persons with disabilities. These legislative acts include laws of Ukraine and acts of the Cabinet of Ministers of Ukraine and the Ministry of Health of Ukraine. It was found that the national legislation does not contain special guarantees for persons with disabilities regarding their protection against infectious diseases, does not provide for special measures of public administration in this area, which would be aimed at meeting the needs of persons with disabilities. Therefore, there is a need for legislation to address the needs of persons with disabilities in all aspects of public policy to protect the population from infectious diseases, ensuring access of persons with disabilities to medical and other services in infectious crises, ensuring access to information about infectious diseases for persons with disabilities all nosologies, collection of statistical data on the incidence of infectious diseases among persons with disabilities, etc.

Emphasis is placed on the importance of civil society participation in the field of social and legal protec- 
tion of persons with disabilities in decision-making on protection and control of infectious diseases to ensure the rights and legitimate interests of persons with disabilities, as all measures to prevent, treat and eliminate infectious diseases should take into account the aspect of disability. In the context of outbreaks of infectious dis- eases, it is vital to ensure access for persons with disabilities (especially those in institutional care or in need of ongoing care) to all services provided to the population, especially medical services.

Key words: person with disability, infectious disease, pandemic, public policy, health care. 